\title{
Perbandingan Kemampuan Pemahaman Matematis Siswa Antara Yang MenggunaKan PEMbelajaran InSIDE-OUTSIDE- Circle Dengan Konvensional
}

\section{THE COMPARISON OF STUDENTS' MATHEMATICAL UNDERSTANDING BETWEEN INSIDE-OUTSIDE-CIRCLE LEARNING AND CONVENTIONAL}

\author{
Reni Nuraeni ${ }^{1}$ dan Irena Puji Luritawaty ${ }^{2}$ \\ 1Program Studi Pendidikan Matematika, STKIP Garut \\ Garut, Jawa Barat, Indonesia \\ reni.n2409@gmail.com \\ 2Program Studi Pendidikan Matematika, STKIP Garut \\ Garut, Jawa Barat, Indonesia \\ irenapuji@yahoo.com
}

\begin{abstract}
Abstrak
Pemahaman merupakan aspek fundamental serta kemampuan dasar untuk mencapai kemampuan matematis lainnya yang lebih tinggi. Setiap pembelajaran harus menyertakan hal pokok dari pemahaman. Untuk meningkatkan kemampuan pemahaman matematis harus difasilitasi oleh pembelajaran yang diberikan oleh guru, salah satunya adalah pembelajaran Inside-Outside-Circle. Penelitian ini bertujuan untuk menelaah perbandingan kemampuan pemahaman matematis siswa antara yang menggunakan pembelajaran Inside-Outside-Circle dengan konvensional. Adapun populasi yang digunakan dalam penelitian ini yaitu siswa kelas IX di salah satu Madrasah Tsanawiyah (MTs) swasta di kabupaten Garut. Sedangkan sampelnya yaitu siswa kelas IX B dan IX C di sekolah tersebut. Instrumen yang digunakan dalam penelitian ini berupa soal uraian yang diujikan pada saat pretest dan posttest. Data hasil tes tersebut kemudian dikenakan beberapa uji statistik yaitu uji normalitas, uji homogenitas, dan terakhir uji-t. Berdasarkan analisis data, dapat disimpulkan bahwa kemampuan pemahaman matematis siswa yang menggunakan pembelajaran Inside-Outside-Circle lebih baik daripada konvensional.

Kata Kunci: Model Pembelajaran Inside-Outside-Circle, Kemampuan Pemahaman Matematis..
\end{abstract}

\begin{abstract}
Understanding is a fundamental aspect as well as a basic ability to achieve other higher mathematical abilities. Every lesson should include the essentials of understanding. To improve the ability of mathematical understanding must be facilitated by the learning provided by the teacher, one of them is the Inside-Outside-Circle learning. This study aims to examine the comparison of students' mathematical comprehension skills between those using the conventional Inside-Outside-Circle learning. The population used in this study is the students of class IX in one of the private Madrasah Tsanawiyah (MTs) in Garut district. While the sample is the students of class IX B and IX C at the school. The instrument used in this study is a description of the tested test at the time of pretest and posttest. Data test results are then subjected to several statistical tests namely normality test, homogeneity test, and last t-test. Based on data analysis, it can be concluded that students' mathematical understanding ability using InsideOutside-Circle learning is better than conventional.

Keyword: Inside-Outside-Circle Learning Model, Mathematical Understanding Skill.
\end{abstract}




\section{Pendahuluan}

Matematika merupakan salah satu mata pelajaran yang sangat penting, karena matematika memiliki fungsi dan kegunaan dalam kehidupan sehari-hari serta memiliki peranan penting bagi mata pelajaran yang lain. Matematika dipelajari oleh siswa dari sekolah tingkat dasar sampai dengan tingkat tinggi. Oleh karena itu, perlu perhatian yang serius dalam menyajikan pembelajaran matematika di kelas, sehingga apa yang menjadi tujuan pembelajaran matematika akan tercapai.

Menurut KTSP tahun 2006, tujuan pembelajaran matematika salah satunya adalah memahami konsep matematika, menjelaskan keterkaitan antar konsep dan mengaplikasikan konsep atau algoritma, secara luwes, akurat, efisien, dan tepat, dalam pemecahan masalah. Dari pernyataan tadi terlihat jelas bahwa pemahaman matematis merupakan aspek yang sangat penting dalam pembelajaran matematika. Pemahaman merupakan dasar untuk memperoleh kemampuan matematis yang lebih tinggi. Ini senada dengan pendapat yang dikemukakan oleh O'Connell (2007:18) yang menyatakan bahwa "Dengan pemahaman matematis, siswa akan lebih mudah dalam memecahkan permasalahan karena siswa akan mampu mengaitkan serta memecahkan permasalahan tersebut dengan berbekal konsep yang sudah dipahaminya".

Pembelajaran matematika hendaknya dikemas dan disajikan oleh guru sesuai dengan tujuan matematika yang hendak dicapai, serta harus bisa memfasilitasi siswa untuk mencapai kemampuan matematisnya. Dalam hal ini adalah kemampuan dasar siswa yaitu kemampuan pemahaman matematis. Sesuai dengan pernyataan Mayer; Olsson \& Rees; Perkins \& Simmons (Hiebert dan Carpenter dalam Dahlan, 2011:4.3) bahwa pemahaman merupakan aspek fundamental dalam pembelajaran, sehingga model pembelajaran harus menyertakan hal pokok dari pemahaman.

Pemahaman matematis menurut Skemp (dalam Soemarmo, 2000) dibedakan menjadi dua jenis yaitu pemahaman instrumental dan relasional. Pemahaman instrumental adalah menghafal sesuatu secara terpisah atau dapat menerapkan sesuatu pada perhitungan sederhana dan mengerjakan sesuatu secara alogaritmatik. Pemahaman relasional adalah kemampuan mengaitkan beberapa konsep yang saling berhubungan, meliputi mengaitkan antara konsep yang satu dengan konsep lainnya, menginterpretasi grafik atau gambar, mengabstraksi pernyataan verbal ke formula atau simbol matematika dan kemahiran siswa menggunakan strategi untuk menyelesaikan soal.

Berikut merupakan indikator dari pemahaman matematis yang disebutkan Dahlan (2011: 4.5):

a. Kemampuan menyatakan ulang konsep yang telah dipelajari. 
b. Kemampuan mengklasifikasikan objek-objek berdasarkan dipenuhi atau tidaknya persyaratan yang membentuk konsep tersebut.

c. Kemampuan menerapkan konsep secara algoritma.

d. Kemampuan memberikan contoh dan counter example dari konsep yang telah dipelajari.

e. Kemampuan menyajikan konsep dalam berbagai macam bentuk representasi matematika.

f. Kemampuan mengaitkan berbagai konsep (internal dan eksternal matematika).

g. Kemampuan mengembangkan syarat perlu dan atau syarat cukup suatu konsep.

Salah satu model pembelajaran yang bisa memfasilitasi tercapainya kemampuan pemahaman matematis siswa adalah model pembelajaran InsideOutside-Circle (IOC). Model ini merupakan model pembelajaran yang dikembangkan oleh Spencer Kagan pada tahun 1990. Model pembelajaran IOC diawali dengan memposisikan siswa menjadi dua buah lingkaran dengan arah berlawanan. Separuh siswa di kelas berdiri membentuk lingkaran dengan menghadap ke luar, dan separuh lagi membentuk lingkaran di luar lingkaran yang pertama dengan menghadap ke dalam, sehingga siswa yang sejajar saling berhadapan. Setelah itu masing-masing siswa bergeser secara bergantian dengan arah yang berlawanan untuk bertukar informasi mengenai materi yang sebelumnya sudah ditugaskan (masing-masing siswa mendapat tugas yang berbeda). Hal tersebut membuat masing-masing siswa mendapatkan pasangan yang baru untuk berbagi.

Dilihat dari langkah pembelajaran IOC, siswa bertukar dan berbagi informasi yang berkaitan dengan materi yang sedang dipelajari. Siswa pada tahap ini memiliki rasa tanggung jawab untuk memahami apa yang menjadi tugas mereka yang nantinya akan dibagi ke teman lainnya. Proses ini akan memfasilitasi siswa untuk meningkatkan pemahaman matematisnya. Selain itu, keterampilan siswa dalam berkomunikasi lisan untuk menyampaikan apa yang sudah dipahaminya akan semakin terasah. Peran guru dalam pembelajaran IOC hanya sebagai fasilitator serta meluruskan jika terjadi kesalahan siswa dalam pemahaman konsep matematika.

Langkah pembelajaran IOC tersebut sesuai dengan indikator pemahaman matematis yang diambil dalam penelitian ini, yaitu kemampuan mengaitkan konsep internal matematika, kemampuan menerapkan konsep secara algoritma, dan kemampuan mengabstraksi pernyataan verbal ke formula atau simbol matematika.

Berdasarkan uraian di atas, penulis tertarik untuk melakukan penelitian dengan judul "Perbandingan Kemampuan Pemahaman Matematis Siswa antara yang Menggunakan Pembelajaran InsideOutside-Circle dengan Konvensional", dengan rumusan masalah sebagai berikut: "Apakah kemampuan pemahaman matematis siswa yang memperoleh 
pembelajaran Inside-Outside-Circle lebih baik daripada siswa yang memperoleh pembelajaran ceramah biasa?". Adapun hipotesisnya yaitu kemampuan pemahaman matematis siswa yang memperoleh pembelajaran Inside-OutsideCircle lebih baik daripada siswa yang memperoleh pembelajaran ceramah biasa.

\section{Metode}

Penelitian ini menggunakan metode kuasi eksperimen dengan sampel yang dipilih yaitu satu kelompok eksperimen dan satu kelompok kontrol. Kelompok eksperimen menggunakan pembelajaran dengan model Inside-Outside-Circle, sedangkan kelompok sampel menggunakan pembelajaran ceramah biasa. Adapun desain penelitian yang digunakan yaitu pretest-posttest control group design sebagai berikut:

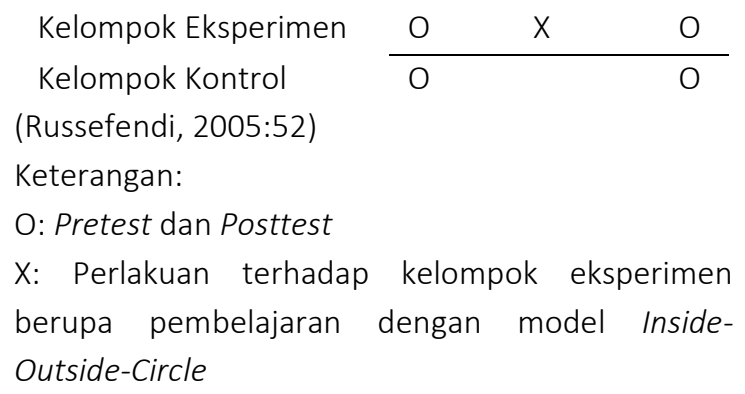

Penelitian ini dilakukan di salah satu Madrasah Tsanawiyah (MTs) swasta di kabupaten Garut pada bulan Oktober 2016. Adapun populasinya yaitu siswa kelas IX di MTs tersebut, dengan sampel yaitu siswa kelas IX B sebagai kelas eksperimen dan siswa kelas IX C sebagai kelas kontrol.

Data yang diperoleh dalam penelitian ini terdiri dari data hasil tes awal (pretest) dan data hasil tes akhir (posttest) dari kedua kelas. Data tersebut kemudian dianalisis secara statistika deskriptif dan inferensi. Pengolahan statistik data dilakukan dengan bantuan SPSS 16.0. Adapun analisis data yang dilakukan diawali dengan uji normalitas data, kemudian dilanjutkan dengan uji homogenitas, dan diakhiri dengan uji-t.

\section{Hasil dan Pembahasan}

Analisis data yang dilakukan bertujuan untuk mengetahui perbandingan kemampuan pemahaman matematis siswa antara yang menggunakan pembelajaran Inside-Outside-Circle dengan konvensional. Adapun gambaran data yang diperoleh dari hasil pretest dan posttest secara umum yaitu sebagai berikut:

Tabel 1.

Data Statistik Skor Kemampuan Pemahaman Matematis

\begin{tabular}{|cccccc|}
\hline \multicolumn{1}{|c}{ Variabel } & \multirow{2}{*}{$\begin{array}{c}\text { Data } \\
\text { Statistik }\end{array}$} & \multicolumn{2}{c}{ Kelas Kontrol } & \multicolumn{2}{c}{ Kelas Eksperimen } \\
\cline { 2 - 6 } & $N$ & Pretest & Posttest & Pretest & Posttest \\
\cline { 2 - 6 } & & 24 & 24 & 24 & 24 \\
\hline \multirow{3}{*}{$\begin{array}{l}\text { Kemampuan } \\
\text { Pemahaman }\end{array}$} & $\mathrm{X}_{\max }$ & 55 & 78 & 55 & 90 \\
\cline { 2 - 6 } Matematis & $\mathrm{X}_{\min }$ & 15 & 20 & 4 & 34 \\
\cline { 2 - 6 } & $\bar{x}$ & 30.42 & 51.79 & 25.63 & 62.17 \\
\cline { 2 - 6 } & $\mathrm{SD}$ & 12.07 & 15.50 & 12.53 & 18.40 \\
\hline
\end{tabular}


Dilihat dari Tabel 1 diketahui bahwa pada tes awal sebelum diberi perlakuan (pretest), nilai yang diperoleh kedua kelas cukup seimbang. Walaupun tampak berbeda tetapi selisih yang ada hanya sedikit sehingga dapat dianggap tidak terdapat perbedaan kemampuan pemahaman awal antara kedua kelas. Berbeda halnya dengan hasil tes setelah diberikan perlakuan (posttest). Dilihat dari segi rerata, hasil posttest kelas eksperimen lebih tinggi dibandingkan dengan kelas kontrol. Adapun selisih reratanya cukup besar yaitu 10.38. Hal tersebut menunjukan bahwa kemampuan pemahaman matematis siswa yang menggunakan pembelajaran Inside Outside Circle lebih baik daripada konvensional. Langkah selanjutnya setelah dilakukan pendeskripsian data yaitu mengolah data secara statistik inferensi untuk menguji hipotesis pada peneitian ini.

\section{A. Uji Statistik Data Hasil Pretest Kemampuan Pemahaman Matematis}

Uji statistik pertama yang dikenakan terhadap hasil pretest yaitu uji normalitas. Adapun hasilnya yaitu sebagai berikut:

Tabel 2.

Hasil Uji Normalitas Data Pretest Kelas Kontrol

\section{Tests of Normality}

\begin{tabular}{|c|r|r|r|r|r|r|}
\hline \multirow{2}{*}{} & \multicolumn{3}{|c|}{ Kolmogorov-Smirnove } & \multicolumn{3}{c|}{ Shapiro-Wilk } \\
\cline { 2 - 7 } & Statistic & \multicolumn{1}{c|}{$\mathrm{df}$} & \multicolumn{1}{c|}{ Siq } & Statistic & \multicolumn{1}{c|}{ df } & Sig. \\
\hline kontrol & .139 & 24 & $.200^{\prime}$ & .928 & 24 & .088 \\
\hline
\end{tabular}

a. Lilliefors Significance Correction

*. This is a lower bound of the true significance.

Tabel 3.

Hasil Uji Normalitas Data Pretest Kelas Eksperimen

\section{Tests of Normality}

\begin{tabular}{|c|r|r|r|r|r|r|}
\hline & \multicolumn{3}{|c|}{ Kolmogorow-Smimove } & \multicolumn{3}{c|}{ Shapiro-Wilk } \\
\cline { 2 - 7 } & Statistic & \multicolumn{1}{|c|}{$\mathrm{df}$} & \multicolumn{1}{c|}{ Siq } & Statistic & \multicolumn{1}{c|}{ df } & Siq. \\
\hline eksperimen & .177 & 24 & .051 & .954 & 24 & .333 \\
\hline
\end{tabular}

a. Lilliefors Significance Correction

Berdasarkan Tabel 2 dan Tabel 3, tersebut lebih besar dari 0.05. Oleh karena diketahui bahwa nilai sig kelas kontrol nilai sig $>0.05$ berada di daerah sebesar 0.088, sedangkan kelas penerimaan Ho, maka dapat diketahui eksperimen sebesar 0.333. Kedua nilai bahwa pada taraf kepercayaan 95\%, data 
hasil pretest kedua kelas berdistribusi homogenitas dan uji-t. Adapun hasilnya normal. Uji statistik selanjutnya yaitu uji yaitu sebagai berikut:

Tabel 4.

Hasil Uji Homogenitas dan Uji-t Data Pretest Kemampuan Pemahaman Matematis

Independent Samples Test

\begin{tabular}{|c|c|c|c|c|}
\hline \multicolumn{5}{|c|}{ nilai } \\
\hline & & & $\begin{array}{c}\text { Equal } \\
\text { variances } \\
\text { assumed } \\
\end{array}$ & $\begin{array}{c}\text { Equal } \\
\text { variances not } \\
\text { assumed } \\
\end{array}$ \\
\hline $\begin{array}{l}\text { Levene's Test for Equality } \\
\text { of Variances }\end{array}$ & $\begin{array}{l}\text { F } \\
\text { Sig. }\end{array}$ & & $\begin{array}{l}.002 \\
.961 \\
\end{array}$ & \\
\hline $\begin{array}{l}\text { t-test for Equality of } \\
\text { Means }\end{array}$ & $\begin{array}{l}\text { t } \\
\text { df } \\
\text { Sig. (2-tailed) } \\
\text { Mean Difference } \\
\text { Std. Error Difference } \\
95 \% \text { Confidence Interval } \\
\text { of the Difference }\end{array}$ & $\begin{array}{l} \\
\text { Lower } \\
\text { Upper }\end{array}$ & $\begin{array}{r}1.349 \\
46 \\
.184 \\
4.792 \\
3.551 \\
-2.356 \\
11.939 \\
\end{array}$ & $\begin{array}{r}1.349 \\
45.936 \\
.184 \\
4.792 \\
3.551 \\
-2.356 \\
11.939 \\
\end{array}$ \\
\hline
\end{tabular}

Hasil uji homogenitas (uji Levene) pada Tabel 4 menunjukan nilai sig sebesar 0.961. Nilai tersebut lebih besar dari 0.05 atau berada pada daerah penerimaan Ho, sehingga varians skor pretest kemampuan pemahaman matematis kedua kelas homogen. Selanjutnya pada uji t (t-test), diperoleh nilai sig sebesar 0.184. Nilai tersebut juga berada pada daerah penerimaan Ho, sehingga dapat disimpulkan bahwa pada taraf kepercayaan 95\%, tidak terdapat perbedaan kemampuan awal pemahaman matematis antara kelas eksperimen dan kelas kontrol.

\section{B. Uji Statistik Data Hasil Posttest Kemampuan Pemahaman Matematis}

Pengujian statistik yang pertama terhadap hasil posttest yaitu uji normalitas. Adapun hasilnya yaitu sebagai berikut:

Tabel 5.

Hasil Uji Normalitas Data Posttest Kelas Kontrol

\section{Tests of Normality}

\begin{tabular}{|c|r|r|r|r|r|c|}
\hline \multirow{2}{*}{} & \multicolumn{3}{|c|}{ Kolmogorow-Smirnov } & \multicolumn{3}{c|}{ Shapiro-Wilk } \\
\cline { 2 - 7 } & Statistic & \multicolumn{1}{c|}{$\mathrm{df}$} & \multicolumn{1}{c|}{ Sig. } & Statistic & \multicolumn{1}{c|}{ df } & Sig. \\
\hline kontrol & .121 & 24 & $.200^{\circ}$ & .958 & 24 & .405 \\
\hline
\end{tabular}

a. Lilliefors Significance Correction

*. This is a lower bound of the true significance. 
Tabel 6.

Hasil Uji Normalitas Data Posttest Kelas Eksperimen

\section{Tests of Normality}

\begin{tabular}{|c|r|c|c|c|c|c|}
\hline & \multicolumn{3}{|c|}{ Kolmogorov-Smirnov } & \multicolumn{3}{c|}{ Shapiro-Wilk } \\
\cline { 2 - 7 } & Statistic & df & Siq. & Statistic & df & Siq. \\
\hline eksperimen & .125 & 24 & $.200^{\prime}$ & .944 & 24 & .203 \\
\hline
\end{tabular}

a. Lilliefors Significance Correction

*. This is a lower bound of the true significance.

Berdasarkan Tabel 5 dan Tabel 6, penerimaan Ho, maka dapat diketahui diketahui bahwa nilai sig kelas kontrol bahwa pada taraf kepercayaan 95\%, data sebesar 0.405, sedangkan kelas hasil posttest kedua kelas berdistribusi eksperimen sebesar 0.203. Kedua nilai normal. Uji statistik selanjutnya yaitu uji tersebut lebih besar dari 0.05. Oleh karena homogenitas dan uji-t. Adapun hasilnya nilai sig > 0.05 berada di daerah yaitu sebagai berikut:

Tabel 7.

Hasil Uji Homogenitas dan Uji-t Data Posttest Kemampuan Pemahaman Matematis

Independent Samples Test

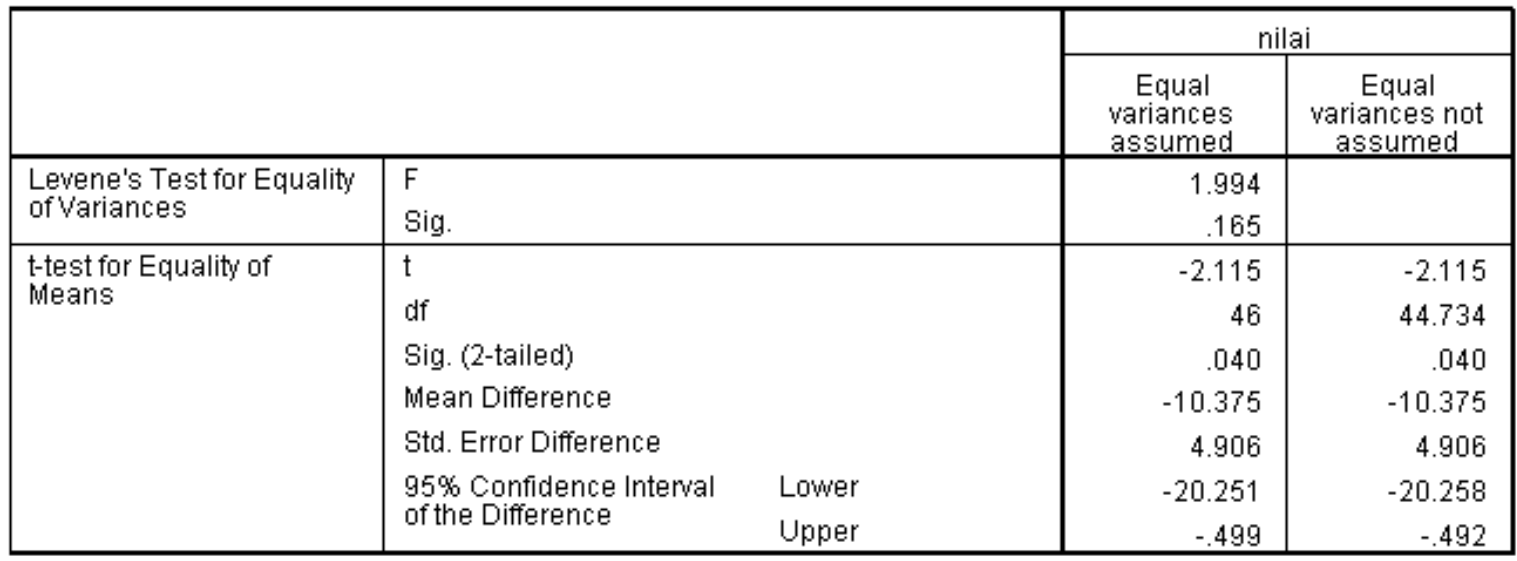

Hasil uji homogenitas (uji Levene) pada Tabel 7 menunjukan nilai sig sebesar 0.165. Nilai tersebut lebih besar dari 0.05 atau berada pada daerah penerimaan Ho, sehingga varians skor posttest kemampuan pemahaman matematis kedua kelas homogen. Selanjutnya pada uji t (t-test), diperoleh nilai sig sebesar 0.040. Nilai tersebut berada pada daerah penolakan
Ho karena kurang dari 0.05, sehingga dapat disimpulkan bahwa pada taraf kepercayaan 95\%, kemampuan akhir pemahaman matematis siswa yang menggunakan pembelajaran InsideOutside-Circle lebih baik daripada konvensional.

Hasil bahwa pembelajaran InsideOutside-Circle efektif untuk 
mengembangkan

kemampuan

pemahaman matematis disebabkan oleh beberapa kelebihan yang dapat dimaksimalkan selama proses pembelajaran. Misalnya dari segi keaktifan siswa. Melalui pembelajaran InsideOutside-Circle, siswa yang awalnya hanya bisa menunggu mendapatkan materi dari gurunya, secara bertahap mulai menggali kemampuannya untuk dapat aktif berbagi informasi dengan temannya. Para siswa dapat belajar lebih mudah karena belajar dengan tutor sebaya sehingga tidak ada rasa canggung ataupun terbentur pada bahasa yang baku seperti ketika berbicara dengan guru. Keadaan tersebut membuat suasana kelas menjadi hidup dan menyenangkan. Adapun dari segi konten materi, penyebarannya dapat dilakukan secara merata karena perputaran yang terdapat pada pembelajaran InsideOutside-Circle membuat siswa mendapatkan semua materi secara bergantian.

Pembelajaran Inside-Outside-Circle membuat semua siswa terlibat dalam proses pembelajaran. Tidak ada lagi siswa yang malas ataupun mengantuk. Hal tersebut dapat membantu siswa lebih fokus selama pembelajaran berlangsung, sehingga nilainya pun menjadi lebih tinggi dari sebelumnya.

Pembelajaran Inside-Outside-Circle memfasilitasi siswa untuk mengasah kemampuan pemahaman matematisnya melalui tahapan saling bertukar dan berbagi informasi mengenai materi yang sedang dipelajari. Siswa akan senantiasa memiliki rasa tanggung jawab mengenai tugas yang harus mereka pahami untuk dibagikan dan ditukar dengan teman sebayanya di dalam kelas. Selain itu, komunikasi lisan siswa untuk menyampaikan apa yang sudah mereka pahami akan semakin terasah dalam pembelajaran. Hal ini akan menciptakan suasana pembelajaran di kelas lebih aktif dan menyenangkan.

Adapun kendala yang dihadapi dalam pembelajaran Inside-Outside-Circle yaitu efektifitas waktu, karena cukup sulit mengkondisikan siswa untuk tertib selama pembelajaran berlangsung, terutama pada jam pelajaran terakhir dimana konsentrasi siswa sudah terpecah. Kendala tersebut dapat membuat suasana kelas menjadi gaduh dan tidak terkendali, sehingga pembelajaran Inside-Outside-Circle tidak akan dapat terlaksana sebagaimana seharusnya.

\section{Penutup}

Berdasarkan hasil penelitian dan pengolahan data, diperoleh kesimpulan bahwa kemampuan pemahaman matematis siswa yang menggunakan pembelajaran Inside-Outside-Circle lebih baik daripada konvensional. Adapun beberapa hal yang dapat disarankan oleh peneliti yaitu sebagai berikut: Pembelajaran Inside-Outside-Circle dapat dijadikan salah satu pilihan dalam upaya mengembangkan kemampuan pemahaman matematis di tingkat MTs; (2) Pembelajaran Inside-Outside-Circle disarankan bagi peneliti selanjutnya untuk 
dilakukan pada kegiatan pembelajaran matematika pada jenjang yang lebih tinggi dan pada kemampuan matematika yang lainnya; (3) Pembelajaran Inside-OutsideCircle tidak disarankan dilakukan pada kelas dengan aktivitas siswa yang hiperaktif; dan (4) Pembelajaran InsideOutside-Circle disarankan dilakukan secara kontinu untuk memantau efektivitas dari pelaksanaan pembelajaran tersebut.

\section{DAfTAR PUStaka}

Dahlan, J. A. (2011). Analisis Kurikulum Matematika. Jakarta: Universitas Terbuka.

Depdiknas. (2006). Kurikulum Tingkat Satuan Pendidikan (KTSP). Jakarta: Depdiknas.

O'Connell, S. (2007). Introduction to Connection. Boston: Heinemann.

Soemarmo, U. (2000). Proses Belajar dan Pemahaman Materi Kuliah. Makalah disampaikan pada lokakarya Peran Pedagogi dalam Peningkatan Proses
Pembelajaran TPB ITB di Bandung pada tanggal 4 Desember 2000.

Russefendi, H. E.T. (2005). Dasar-Dasar Penelitian Pendidikan \& Bidang NonEksakta Lainnya. Bandung: Tarsito.

\section{Riwayat Hidup PENULIS}

Reni Nuraeni, M. Pd.

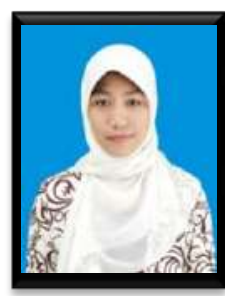

Lahir di Garut, 15 Agustus 1988. Staf pengajar di Sekolah Tinggi Keguruan dan Ilmu Pendidikan Garut. Studi S1 Pendidikan Matematika Sekolah Tinggi Keguruan dan Ilmu Pendidikan Garut, lulus tahun 2010; S2 Pendidikan Matematika Universitas Pendidikan Indonesia, lulus tahun 2014.

\section{Irena Puji Luritawaty, M. Pd.}

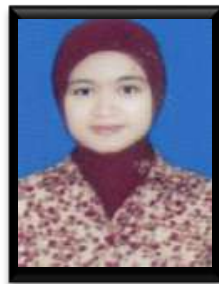

Lahir di Tangerang, 30 April 1988. Staf pengajar di Sekolah Tinggi Keguruan dan Ilmu Pendidikan Garut. Studi S1 Pendidikan Matematika Sekolah Tinggi Keguruan dan Ilmu Pendidikan Garut, lulus tahun 2010; S2 Pendidikan Matematika Universitas Pendidikan Indonesia, lulus tahun 2014. 
This page is intentionally left blank 